\title{
ARTIGO
}

do https://doi.org/10.22481/praxisedu.v16i37.6164

\section{DETERMINATION OF SOCIAL NETWORKS IN THE CONTEXT OF SOCIAL CHANGE, TECHNOLOGY AND EDUCATION ACCORDING TO THE OPINIONS OF SCHOOL ADMINISTRATORS}

\author{
DETERMINACIÓN DE LAS REDES SOCIALES EN EL CONTEXTO DEL CAMBIO \\ SOCIAL, LA TECNOLOGÍA Y LA EDUCACIÓN SEGÚN LAS OPINIONES DE LOS \\ ADMINISTRADORES ESCOLARES
}

DETERMINAÇÃO DE REDES SOCIAIS NO CONTEXTO DE MUDANÇA SOCIAL, TECNOLOGIA E EDUCAÇÃO DE ACORDO COM AS OPINIÕES DOS

ADMINISTRADORES ESCOLARES

Behcet $\ddot{O}_{z n a c a r}$

Near East University - Turquia

\begin{abstract}
This research was carried out according to the semi-structured interview form developed by the school principals and researchers working in the Nicosia and Kyrenia districts in 2018/19 academic year. Within the scope of the research, the dimension of social change and the effect of technology on this process have been discussed. The relationship between the social change and the technology was argued in the context of education and then the situations which were realized by the interaction of three concepts were expressed. Moreover, it has been emphasized that positive developments can be experienced by benefiting from the potential of social networks in social change, technology and education triangle, and that the same potential may be damaging if some cases are ignored.
\end{abstract}

Keywords: Social network; Technology; Social change; Administrators.

Resumen: Esta investigación se realizó de acuerdo con el formulario de entrevista semiestructurada desarrollado por los directores de las escuelas y los investigadores que trabajan en los distritos de Nicosia y Kyrenia en el año académico 2018/19. Dentro del alcance de la investigación, se ha discutido la dimensión del cambio social y el efecto de la tecnología en este proceso. La relación entre el cambio social y la tecnología se discutió en el contexto de la educación y luego se expresaron las situaciones que se realizaron por la interacción de tres conceptos. Además, se ha enfatizado que se pueden experimentar desarrollos positivos al beneficiarse del potencial de las redes sociales en el cambio social, la tecnología y el triángulo educativo, y que el mismo potencial puede ser perjudicial si se ignoran algunos casos.

Palabras clave: Red social; Tecnología; Cambio social; Administradores. 
Resumo: Esta pesquisa foi realizada de acordo com o formulário de entrevista semiestruturada desenvolvido pelos diretores da escola e pesquisadores que trabalham nos distritos de Nicósia e Kyrenia no ano letivo de 2018/19. No âmbito da pesquisa, a dimensão da mudança social e o efeito da tecnologia nesse processo foram discutidos. A relação entre mudança social e tecnologia foi discutida no contexto da educação e, em seguida, foram expressas as situações que foram realizadas pela interação de três conceitos. Além disso, enfatizou-se que desenvolvimentos positivos podem ser experimentados se beneficiando do potencial das redes sociais no triângulo das mudanças sociais, tecnologia e educação, e que o mesmo potencial pode ser prejudicial se alguns casos forem ignorados.

Palavras-chave: Rede social; Tecnologia; Mudança social; Administradores.

\section{Introduction}

From past to now the use of social media has been increasing and becoming an indispensible part of daily life. Therefore, it is not just affecting our social relations, but also affecting our professional relationships, and educational life. In this context social networks that has become one of the means of communication has began to affect the relationship among student, parent, teacher and school administrators. According to the researches done in the same field, it has been found that the use of social network is less in Cyprus and Turkey compared to the other developed countries. In this context, efforts are being made to support teachers and their teaching processes through platforms such as the Education Information Network (EBA) for them to keep themselves updated in terms of new tehncological developments. Another important aspect to be considered in the same subject is the new generation is more willing and open to learn to use digital technologies in class. In this regard, despite the fact that this can give an opportunity for young population, a significant number of teachers are left behind compared to their students which may create an important problem. So, it is vital that school administrators take a big role and demonstrate leadership in terms of the effective use of these technologies in all areas of education.

School administrators leading to the use of technology is enabling students to be more motivated in class as they would feel, it would be easier for them to learn in such an environment in which technology is allowed to be used both by the students' and the teachers'. Accordingly, school administrators encouraging the use of technology in their institutions should be seen as a common value, and they should encourage the use of digital resources, create a digital learning culture that is integrated into the educational process for students who are interested in using 
digital resources to maintain the legal and ethical standards required by digital culture (Köse, Yurdakul and Onuk, 2017).

\section{The Use of Social Media in Educational Institutions}

Social media is creating an individual learning environment and there are a number of studies demonstrating that they provide important contributions for people's formal and informal learning experiences. As Mazman and Usluel (2010) claimed social network tools are providing great help to students' in their educational activities by making collaboration, active participation, interaction, searching information and sharing resource, and encouraging critical thinking. Plus, it would help students to simplify this process as they spend a lot of their time using online applications. Research done on this topic so far is very limited, and therefore, has arousen the need to do further research on social networks in educational context. As we all know, facebook is the most popular and commonly used social networking site besides, hundreds of others. For Mason (2006) facebook has been considered as an educational tool because it enables peer communication, peer feedback, active participation and collaboration. These applications serve to a wide range of interests, needs and views of all people. However, young people are mostly using them to communicate or contact with their loved ones such as friends or family, to share personal information and materials. This can be seen as the positive side of using social networking sites outside the classroom environment since it plays an important role in continuing the education given in class. For this reason, it can be said that social networking sites in an academic context is more attractive for young learners because in this way, they will be given more chance to learn new information through effective and easier learning process. Like this they will be taking part in interactive situations while having fun and enjoyment supported with the help of motivating tools. According to researchers, social networks develop skills for communication and can be easily integrated into students' educational environments. Although, it can be used in educational areas successfully, it may cause some problems to the users such as confidentiality and misuse of information. However, their could be some benefits of it for educators, when searching for conferences, publishing studies, conducting researches, joining in exhange programs, searching for funds, planning courses and activities.

According to Balc1 (2010), social networks has so many advantages and therefore, should be used as an educational tool. These reasons are: 
- It helps autonomous learning

- Generates independence from time and location

- Improves the quality, success and efficiency of education

- Enables individuals to learn more systematically and in shorter time

- Gives a chance to have a quick feedback in the subject matter

- Offers the learners a chance to repeat things as much as they like

- Simplifies the content

- Allows visual and auditory learning

- Enables learners' to practice some laboratory applications through virtual laboraties, animations

- Allows learning by virtual classes

- Gives students' and teachers' a chance to enhance their knowledge, research skills via some programs to reach, use, evaluate, and cite all the information they found

- Offers possibility to evaluate students' performance

Many people see new technologies as powerful tools to help schools and educational needs of learners'. More people and educators are adding social networks to their teaching environments to strengthen their academic skills, to stimulate learning and arouse their interests. In many schools, depending on the financial sitaution of the insitution students are given technologcal tools such as; ipads, laptops, computers and etc. or they are allowed to bring their from home. In this respect, students are being allowed to use technology all day from all locations. According to the researches, it is believed that if the students have technological devices in their hands it will help them to learn at their own pace, to test their knowledge on technological skills, to be prepared for modern workplaces that they will encounter in their future careers, to do more complex and creative work on a digital platform, to improve the management of schools and administration and to improve communications among students, teachers, administrators and parents. Despite the potential benefits, many institutions have encountered with some troubles regarding the use of technology in classes. Paying for the devices can be a problem as it may cost too much, infrastructure may not be adequate enough to support all learners' access to the internet at the same time, and most importantly it may lack vision as to why social networks should be used in education. The combination of traditional teaching and technology based instruction has been given a name called 'blended learning'. This type of learning is trying to cover what students learn in class (face to face) similarly with 
an online program (Öznacar, Kan, Besim \& Şensoy, 2018). Okul Öncesi Dönemde Çocuğa Yönelik Şiddet İçeren TV Programlarının Ebeveynlerin Görüşleriyle Etkilerinin Değerlendirilmesi. BEYİN: Yapay Zeka ve Sinirbilim Üzerine Geniş Bir Araştırma , 9 (4)..

\section{The School Administrators Views On The Use of Social Networks and Technology}

According to Hampton (2016) with the changing time, school administrators are facing with so many difficulties to meet the requirements of today's instutions and to adapt themselves to these changes because they should meet the needs of communities, students' and parents'. For this reason, they are searching to find new ways to get all learners involve in the learning process. Thus, it is very important for school administrators to build good and positive relationships with their stakeholders. Burnett et al. (2009) claimed that ' the use of social networking sites would be effective and efficient way of reaching stakeholder groups once the usage of these sites is understood.' Despite the fact that some people would be against this idea as they would claim that by social network sites the role of the principals and administors would change. According to Hall (2006) online communication does not only strengthen the relationships, but also engages stakeholders more into the school. In today's day and age, school administrators must improve themselves to reach everyone easily and quickly, to gain the support they need from the stakeholders and to find the resources they need by connecting to the social networking sites. In today's educational system communication is very important and therefore, school administrators are looking for different ways to make their communication easier and more effective. Some researches suggested that social networking sites and the use of technology in class is enabling success and developing the knowledge of the students'. Furthermore, it would have benefits on informing the good achievements that are taking place in school to the public. Nevertheless, the negative effect of this may be transparency as everything would be accessible and open like this and there would not be any privacy. With this in mind, school administrators should try to gain the stakeholders trust.

From past to now, teachers have tried to find different ways to attract students' attention and to get them interested in the subject matter. Even today, this battle is still going on. The modern and rapidly developing technology and technological tools are limitless now and social networking sites are used in our daily lives in everything we do. Therefore, as they have become inseperable part of our lives they should be utilized in the right way to get the best out of them and to make everything interesting and relevant for all. Integrating social media to 
education has been a new trend for a long time to optimize learning. According to Friedman and Freidman (2013), 'all educators had to re-consider education and educational tools and set them up again to make them more fun for students and social media has been found as the best way to deal with this.' There are a lot of social networking sites available for all users and all are being used for different purposes. Some are using to engage students into discussions through blogs, some to post assignments, some to send or receive emails regarding students activities and accomplishments, to post photos in the right focus, to create classroom website to give students home based activities, to gather feedbacks on the online discussion forums to find out the needs of all and to send group emais to all parents' and students'.

Nevertheless, there are some worries of school administrators on the use of social networks because they are concerned about what learners and educators do while they are using it. The most important reason for this is, they would not want to see the name of their institutions in the press for any inappropriate behaviour or attitude of the students' and teachers'. So, to avoid this situation they should educate all users on the usage of such things (Dağlı \& Öznacar, 2015). Plus, cyber bullying, manipulation of some contents, replication and privacy issues are other important concerns for administrators. Another concern is anyone can create an official webpage and there is no check on them. At this point, it could be dangerous in terms of the flow and identification of the information and there may be loss of control of the information and inappropriate comment could be made to be seen by everyone. Based on the available literature, regarding the decision given by the school administrators whether or not using the social networks in class would be beneficial to educational environment, a common thought that we came across with was that using social media in classs could be distractive and should be limited in classrooms.

\section{RESULTS}

In this part of the study, the findings of the demographic information belonging to the sample group and the results obtained by the analysis of the data obtained for the sub-problems of the researcher with the appropriate statistical method are included and comments on these findings are given. Below, the pre-test and post-test results that are applied in the seminars and held in different topics within the scope of the research are separately expressed in tables. 


\section{A. Quantitative Data Analysis:}

Table 1. Years Experience As A School Administrator

\begin{tabular}{ll}
\hline Years Experience & N \\
\hline $1-5$ & 3 \\
$6-10$ & 5 \\
$11-15$ & 4 \\
$16-20$ & 8 \\
$21-25$ & 7 \\
\hline
\end{tabular}

In Table 1, the years of experience distribution of the participant administrators working in the Nicosia and Kyrenia districts were (30.2) had 1-5 years, (25.8) had 6-10 years of experience, (21.0) had 11-15 years of experience, (8.2) 16-20 and (3.2) had 21-25 years of experience.

Table 2. Frequency distribution by gender.

\begin{tabular}{lllc}
\hline & & F & \% \\
\hline Gender & Male & 12 & 36 \\
& Female & 15 & 64 \\
& TOTAL & 27 & 100
\end{tabular}

Table 3. Frequecy distribution of participant school administrators by region

\begin{tabular}{lcc}
\hline & F & \% \\
\hline Kyrenia & 12 & 36 \\
Nicosia & 15 & 64 \\
Total & 27 & 100 \\
\hline
\end{tabular}

According to the region distribution of the participants, 12 administrators were from Kyrenia and 15 were from Nicosia. 


\section{Pre-test and Post-test Findings}

\section{A: Qualitative Data Analysis}

Question 1. Positive Effects of Social Networks to Students Behaviours in class

Table 1. School Administrators Opinions on the Positive Effects of Social Networks on Students' Behaviors

\begin{tabular}{llc}
\hline School Administrators Opinions & $\boldsymbol{F}$ & $\%$ \\
\hline Enables positive shares & 5 & 22 \\
& 7 & 24 \\
Helps to the self development & 6 & 21 \\
& 4 & 23 \\
Builds up good communication skills & 6 & \\
Provides fast and easy communication & & \\
Ensures rapid dissemination of announcements & & \\
\hline
\end{tabular}

\section{Participants' opinions;}

It is useful to combine lessons with social networks in order to have the students use the technology well to help to the distribution of announcement in an easy and fast way (Y8).

It helps to the development of individuals and builds up communication skills (Y 10).

When we look at Table 1, we can see that the school administrators see the use of social networks positively. Only $22 \%$ of school administrators $(f=5)$ have expressed that the students are using social networks for positive sharing. In addition to this, other positive things that have been observed in student behaviours; it benefits to the self-development, having better human relations, rapid communication, self-expression and followig what they see beautiful.

Question 2. Negative Effects of Social Networks to Students Behaviours in class Table 2. School Administrators Opinions on the Negative Effects of Social Networks on Students' Behaviors

\begin{tabular}{lll}
\hline & $F$ & $\%$ \\
Theme & 3 & 12 \\
\hline Students wasting their time & 4 & 15 \\
& 3 & 12 \\
Inappropriate sharing and language & 8 & 31 \\
Sharing private information & 9 & 32 \\
Falling behind in lessons & & \\
$\begin{array}{l}\text { Students' behaving irresponsible } \\
\text { via technology usage }\end{array}$
\end{tabular}

\section{Participants' opinions;}

The negative impacts of social networks on students' behavior were observed. 
Using social networks can be harmful for students' as they may fall behind in their lessons due to misuse of it. Although it can have positive effects on students' and in education, if users are not careful as to why they are using it, it may bring harms to educators and students lives.

In table 2, it can be seen that students can be curious about lots of things as of their age and this increasing curiosity of seeing and learning things can be the inappropriate images, texts which adults would not want their children to see that can lead to misbehaviour of students'. Other important negative behaviors observed by school administrators are due to the use of social networks students are wasting their time ineffectively and by coming across with lots of bad images, things and people as a result of technology use their behaviours and manners are being affected negatively.

\section{Question 3. Social Networks Usage and Academic Success}

Table 3. School Administrators Opinions on the Contribution of Social Networks to Academic Success

\begin{tabular}{|c|c|c|}
\hline \multicolumn{3}{|l|}{ Positive Themes } \\
\hline Helps to reach information & 7 & 27 \\
\hline Increases success & 11 & $\begin{array}{l}42 \\
27\end{array}$ \\
\hline Helps to learn more about the world & 1 & 4 \\
\hline $\begin{array}{l}\text { Provides possibility with another teacher } \\
\text { another class (online) }\end{array}$ & 1 & 4 \\
\hline \multicolumn{3}{|l|}{ Helps to the resolution of the difficult problems } \\
\hline & $\boldsymbol{F}$ & $\%$ \\
\hline \multicolumn{3}{|l|}{ Negative themes } \\
\hline Causes addiction & 3 & 12 \\
\hline & 6 & 23 \\
\hline Causes laziness & 1 & 4 \\
\hline $\begin{array}{l}\text { Encourages populer life to be taken as an } \\
\text { example }\end{array}$ & 7 & 27 \\
\hline Replacing books & & \\
\hline
\end{tabular}

\section{Participants' opinions;}


Using social networks in education can help to the increase of success. In order to have more successful students and to provide them an opportunity to reach information easier and quicker Social network use is important. Despite all the negative effects such as; causing laziness, addiction, encouraging people to imitate other lives they see and replacing books.

When Table 3 is examined, it can be seen that the school administrators think that the use of social networks have a positive impact on academic success of students' with the most contribution in themes. The most negative impact of social network use on academic achievement is seen as leading people to imitate other lives with the least percentage. In spite of the positive effects, there are also negative effects of using technology. With the help of the technology participants agreed that it is easier to reach information which is the positive aspect of it. However, they are wasting their time on social media instead of reading books was the negative aspect that has been emphazised.

\section{Question 4. Social networks should be used in educational environments}

Table 4. School Administrators Recommendations on the Use of Social Media for Educational Purposes

\begin{tabular}{lll}
\hline \multicolumn{1}{l}{ Opinions of School Administrators } & $\boldsymbol{F}$ & $\%$ \\
\hline People should be enlightened & 11 & 42 \\
$\begin{array}{l}\text { Education should be given on the } \\
\text { use of social media }\end{array}$ & 1 & 20 \\
$\begin{array}{l}\text { Control mechanism should be improved } \\
\text { Inappropriate shares should be removed } \\
\text { instantly }\end{array}$ & 5 & 4 \\
$\begin{array}{l}\text { Some sites should be limited in use } \\
\begin{array}{l}\text { Parents should take some cares } \\
\text { when their childrens are using }\end{array}\end{array}$ & 2 & 8 \\
\\
$\begin{array}{l}\text { It should be banned for children } \\
\text { Social media networks should be connected to } \\
\text { the Ministry of Education. }\end{array}$
\end{tabular}

\section{Participants' opinions;}

In order to allow the use of social networks in education parents should be enlightened and control mechanism should be settled to control posts on social media. 
Educating people on the positive and negative aspects of social network use is an important step to be taken before students are allowed to use it in class for educational purposes because they should be aware of the good and bad sides of it.

In table 4, according to the administrators, we can see that users of social networking tools should be enlightened and they should be aware of the reasons as to why they should be using them in class for academic purposes. Moreover, administrators think there should be control mechanisms to check why the users are using it for and inappriprate shares should be removed instantly and all should be under the control of the Ministry of Education and parents' for the good of students'.

\section{DISCUSSION}

This research aimed to find, if the use of social networks and technology provide benefits to education or not according to the school administrators opinions. For this reason, it examines administrators attitude toward seeking social network and technolgy use and their place in education and affect on students' as well as providing the reasons and the effects of social network use.

Our study concerns that the use of social networks and technology in class for academic purposes may be risky sometimes due to the differences in students' and their lack of knowledge on why it should be given a chance to be used in classrooms. With the popularity of social media in today's society, the implementation of social media in education presents school administrators with concerns such as; students would be addicted to these, they would be wasting their times on doing some other things with the power of technology in their hands rather than using it only for educational reasons, and they would give up reading books (Debeş, \& Oznacar, 2018). Another concern of administrators were found to be the manipulation of the content of some posts, reduce in the privacy of individuals, and laziness that may cause to individuals as well as being a guide for them to do what they see with the use of technology. Huffman (2013) found similar concerns of administrators like privacy issues, cyber bullying, the replication and manipulation of content posted of the things being posted on social media.

Another finding we have is that people don't have enough education on the benefits of social networks. Therefore, by the data obtained from some administrators it can be said that technology should be avoided to be used for educational purposes. However, others believed that it enables fast and easy communication, and within seconds it reaches to all by building 
positive communication between people which is eventually leading to success and betterment of institutions. Whereas, in Hampton's (2016) and Öznacar \& Dericioğlu (2017) study, it has been found that the lack of knowledge and understanding of social media by the older school administrators leads to their concerns on using social networking tools to communicate with their stakeholders unlike our study because we have no age distribution table given. According to our findings, only a small amount of partipants thought that social networks use should be banned in educational environments and more participants agreed on the fact that it should be controlled by the Ministry of Education to prevent some risks found as a result of this study. However, according to Kaya and Bicen (2016) more chances should be given students to use their smartphones and facebooks in class as they believed that learners are not using their social networks to play a game or to do anything different than they are asked by their teachers.' Therefore, their study suggested that enabling a peaceful social network environment is important as otherwise relationships can be damaged between students. Another similarity found in our results and in Hew's (2011) findings is that despite the negative aspects of it, social network use in class has many advantages for students learning purposes. Both studies revealed that participation in social networks and the use of technolgy has many benefits. However, wrong use of it could have a negative impact on their academic success. The result in this study is consistent with so many other studies and the findings reflect school administrators views on social networks and technology use (Badri et al. (2017).

\section{CONCLUSION}

The findings of this research indicated that the positive rate is higher when the students are using social networking tools and technology in class as it helps to the social change and brings a new light to the educational environment.

In education today, the use of social networking tools is inevitable because in today's society, nearly all people are using smart devices to reach each other and to spread information among their families, collegues and peers. Social networks and technology is also making the job of school administrators easier as with the help of them they are providing quick access to majority of people. The school administrators think, it would give them a greater chance to express their opinions on an online system regardless of the risks they may take such as; mis interpretation and distruption of privacy. Another study could be conducted to find the opinions of the teachers' and students on the same topic. 
As a result of this study sharing information, and ideas and improving administrators communication skills were founded as the benefits of using social networking tools and technology. Although misuse of it could result in failure of students and resullt in bad performance. Therefore, this study shows, the decisions that should be given by the administrators as it is part of their responsibility to make the right decision that would not give any damage to students' life by working collaboratively with the Ministry of Education and may be parents'. Furthermore, if further research is carried out on the same issue students' and teachers' opinions could be reflected on the choice of the situation (social networks and technology) and with the decision they give, positive outcome is expected on the usage of these tools.

The research results in this article have implications for the understanding of the relations between students'and administrators' in terms of social networking. The focus group which was administrators suggested that schools should integrate these tools to their teaching programs so, students don't fall behind the technology as we live in a technolgy driven world. Thus, change is essential to keep ourselves up to date. However, this research is helping us to see that technology and the more use of use it, is adding new teaching methods and techniques that are likely to work with students of this day and age. Hence, as teachers', students' and administrators' all changes in technology should be reviewed and embraced. So that they may lead to the betterment of institutions and improve the knowledge of all in the process of learning which they would be more interested in and they would feel more motivated once they get to involve in it. There is no doubt that this engagement will not just improve administrators', teachers', students' capacity of learning, reaching information, but also the curriculum in the most innovative way within the focus of technology.

\section{REFERENCES}

1. Akbaba-Altun, S. ve Gürer, M. D. (2008). School administrators' perceptions of their roles regarding information technology classrooms. Egitim Arastirmalari-Eurasian Journal of Educational Research, 33, 35-54.

2. Badri, M., Nuaimi, A., A., Guang, Y. and Rashedi, A., A. (2017). School perfomance, social networking effects, and learning of school children: Evidence of reciprocal relationships in Abu Dhabi, 1-12. 
3. Balci, B. (2010). Success factors in the e-learning system. In U. Demiray, G. Yamamoto, M. Cut. (Eds.). E-learning in Turkey: Developments and applications (pp. 465-480).

4. Burnett, E., Lamm, A., Lucas, J., \& Waters, R. (2009). Engaging stakeholders through social networking: how nonprofit organizations are using facebook. Public Relations Review, 35(2), 102-106.

5. Carr, N. (2006a). From transparency to trust. American School Board Journal, 193(9), 68-69.

6. Dabbagh, N. and Kitsantas, A. (2012). Personal learning environments, social media, and selfregulated learning: A natural for connecting formal and informal learning. The Internet and Higher Education, 15(1), 3-8. doi:10.1016/j.iheduc.2011.06.002formula.

7. Dağlı, G. ve Öznacar, B. (2015). Okul Yöneticilerinin, Öğretmenlerin ve Ailelerin Görüşlerine Göre İlköğretim Okullarının Yaygınlaştırma Uygulamalarına Bir Değerlendirme. Eğitim Bilimleri: Kuram ve Uygulama, 15 (5), 1317-1332.

8. Debeş, G., \& Öznacar, B. (2018). Evaluation of the opinions of various actors on the school management of digitalization and management processes of the system engineering model in education. Amazonia Investiga, 7(16), 304-315.

9. Friedman, L.W., \& Friedman, H.H. (2013). Using social media technologies to enhance online learning. Journal of Educators Online, 10(1), 1-22.

10. Gillet, D., El Helou, S., Yu, M. C., \& Salzmann, C. (2008). Turning Web 2.0 social software into versatile collaborative learning solutions, 170-176). IEEE Computer Society Press.

11. Hall, D. (2006). Managing the communications. Learning \& Leading With Technology, 33(6), 18-21.

12. Hampton, N., K. (2016). Social media and political discussion: when online presence silences offline conversation (Online). Retrieved from https://www.tandfonline.com/doi/full/10.1080/1369118X.2016.1218526

13. Herold, B. (2016, February 5). Technology in Education: An Overview. Education Week. Retrieved Month Day, Year from http://www.edweek.org/ew/issues/technology-in-education/

14. Hew, K., F. (2011). Students' and teachers' use of facebook, 662-676.

15. Hsieh, C.C., Yen, H.C. and Kuan, L.Y. (2014). The relationship among principals' technology leadership, teaching innovation, and students' academic optimism in elementary schools, International Conferences on Educational Technologies 2014 and Sustainability, Technology and Education, 113-120.

16. Huffman, S Education, 134(2), 154-160.. (2013). Benefits and pitfalls: Simple guidelines for the use of social networking tools in K-12 education.

17. Kaya, T. And Bicen, H. (2016). The effects of social media on students' behaviors; Facebook as a case study, 374-379. 
18. Köse, K., E., Yurdakul, Ö. ve Onuk, H. (2017). The Investigation of the relationship between school adninistrators leadership in technology and teachers' students' interaction in social media, 1-16.

19. Mason, R. (2006). 'Learning technologies for adult continuing education'. Studies in Continuing Education, 121-133.

20. Mazman, G. S. and Usluel, K. Y. (2010). Modeling educational usage of Facebook, 444-453.

21. Mejias, U. (2005). Nomad's guide to learning and social software. Retrieved 19.05.2008, from.

http://knowledgetree.flexiblelearning.net.au/edition07/download/la mejias.pdf

22. Mitchell, S., Foulger, T. S., \& Wetzel, K. (2009). Ten tips for involving families through internet-based communication. Young Children, 64(5), 46-49.

23. Öznacar, B., Dericioğlu, S. (2017). Teknoloji Kullanımında Okul Yöneticilerinin Rolü. Avrasya Matematik, Fen ve Teknoloji Eğitimi Dergisi , 13 (1), 253-268. https://doi.org/10.12973/eurasia.2017.00615a

24. Öznacar, B., Kan, Ş. G., Besim, S., \& Şensoy, Ş. (2018). Assessment of the Effects of TV Programs Containing Violence on Children in Pre-school Period through the Views of Parents. BRAIN. Broad Research in Artificial Intelligence and Neuroscience, 9(4), 77-82.

25. Reuben, R. (2008). The use of social media in higher education for marketing and communications: A guide for professionals in higher education. Retrieved from http://doteduguru.com/wp-content/uploads/2008/08/social-media-in-higher education.pdf

26. Tiryakioğlu, F. and Erzurum, F. (2011). Use of Social Networks as an Education Tool, 135-150.

\section{SOBRE O AUTOR:}

\section{Behcet ÖZNACAR}

Associate Professor, Near East University, Atatürk Education Faculty, North Cyprus.

E-mail: behcet.oznacar@neu.edu.tr

iD http://orcid.org/0000-0001-6164-1432

Recebido em: 29 de outubro de 2019 Aprovado em: 15 de novembro de 2019

Publicado em: 20 de janeiro de 2020 